\title{
Uji Pupuk Slow Release Urea Dirakit dari Berbagai Bahan Polimer terhadap Pertumbuhan dan Hasil Bawang Merah Tiron pada Tanah Sawah Purwosari
}

\section{Test of Slow Release Urea Fertilizer Assembled from Various Polymer Materials on the Growth and Yield of Tiron Shallots in Purwosari Rice Fields}

\author{
Amatullah Nurul Azizah ${ }^{1}$, Purwandaru Widyasunu ${ }^{2}$, Eny Rokhminarsi ${ }^{3}$ \\ ${ }^{1}$ Mahasiswa Program Studi Agroteknologi, Fakultas Pertanian, Universitas Jenderal Soedirman \\ ${ }^{2,3}$ Dosen Program Studi Agroteknologi, Fakultas Pertanian, Universitas Jenderal Soedirman
}

\begin{tabular}{l} 
ARTICLE INFO \\
\hline Article history: \\
DOI: \\
10.30595/pspfs.v2i.167
\end{tabular}

Submitted:

July 29, 2021

Accepted:

Sept 10, 2021

Published:

Nov 10, 2021

Keywords:

Slow Release Urea, Shallot, ExPaddy Fields of Purwosari Village

\begin{abstract}
This research aims to determine 1) the effect of four formulas on slow release urea on the growth and yield of shallot plant at Purwosari village and 2) formula of slow release urea that have the best growth and yield of shallot plant at Purwosari village. The research was conducted in November 2019 untill Maret 2020 The research was conducted at the expaddy fields of Purwosari village, Baturraden District, Banyumas Regency and Research Laboratory, Jenderal Soedirman University. Research in the form of non-factorial field experiments using RAKL with five treatments repeated five times. The formula of each treatment includes: F0 $=$ NPK (Urea, SP-36, and $\mathrm{KCl}$ ), $\mathrm{F} 1=70 \%$ urea $+6 \%$ chitosan $+24 \%$ humic acid, $\mathrm{F} 2=70 \%$ urea $+10 \%$ Azolla microphylla $+10 \%$ gondorukem $+10 \%$ humic acid, $\mathrm{F} 3=60 \%$ urea $+10 \%$ Azolla microphylla $+10 \%$ montmorillonite $+10 \%$ gondorukem $+10 \%$ humic acid, and $\mathrm{F} 4=56 \%$ urea $+3 \%$ humic acid $+24 \%$ zeolite $+11 \%$ tapioca flour $+6 \%$ gondorukem. The observed variable including growth and yield components of shallot. The variable of growth including the height of plant, the number of leaves, the weight of fresh plant of clump-1, the weight of fresh plant of effective plot, the weight of dry plant of clump-1, the weight of dry plant of effective plot, and the number of clump-1 bulbs. The yield components of shallot is a bulbs. Result of the research showed that the best formula for plant growth and yield of shallot plant is F2. The growth and yield of shallot produced by F4 is always lower than in the control treatment (F0). Farmers can fertilize less and optimize nitrogen uptake by plants with application of slow release of urea.
\end{abstract}

This work is licensed under a Creative Commons Attribution 4.0 International License.

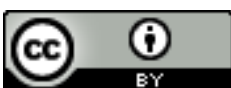

Corresponding Author:

Amatullah Nurul Azizah

Mahasiswa Program Studi Agroteknologi, Fakultas Pertanian

Universitas Jenderal Soedirman

Email: nurulazh334@gmail.com

\section{PENDAHULUAN}

Bawang merah merupakan komoditas hasil pertanian unggulan penting dan prospektif. Kebutuhan bawang merah semakin meningkat seiring bertambahnya penduduk. Kebutuhan bawang merah pada tahun 2016 sebesar 
1.045.483 ton dan diperkirakan akan mengalami peningkatan. Hal tersebut dibuktikan melalui peningkatan hingga tahun 2019 yang mencapai 1,31 juta ton dengan rata-rata pertumbuhan sebesar 3,26\% per tahun (Kurniasari et al., 2017). Berdasarkan data Pusdatin (2015), produksi bawang merah di Indonesia selama 5 tahun berurut-urut $(2015,2016,2017,2018$, dan 2019) mengalami peningkatan, yaitu 1.173.162 ton, 1.207.256 ton, 1.241.350 ton, 1.275.444 ton, dan 1.309.539 ton dengan rata-rata pertumbuhan per tahun sebesar 1,24\%.

Ketersediaan hara dalam tanah yang cukup dan seimbang merupakan salah satu kunci keberhasilan budidaya bawang merah (Jamilah et al., 2017). Menurut Sutedjo (2010), pemupukan merupakan penambahan unsur hara yang dibutuhkan oleh tanaman. Pratomo et al. (2009) menyatakan bahwa pupuk nitrogen yang sering ditemui di pasaran Indonesia adalah urea dan ZA. Permasalahan yang sering dihadapi di lapang dalam penggunaan pupuk urea adalah ketidakefisienan pupuk. Nainggolan et al. (2009) menyatakan pupuk dalam bentuk slow release fertilizer (SRF) dapat mengoptimalkan penyerapan nitrogen oleh tanaman sesuai dengan waktu dan jumlah yang dibutuhkan tanaman, serta mempertahankan keberadaan nitrogen dalam tanah dan jumlah pupuk yang diberikan lebih kecil dibanding dengan metode konvensional.

Salah satu alasan menggunakan bawang merah varietas Tiron karena varietas tersebut tahan pada musim penghujan. Menurut Handayani et al. (2005), keunggulan utama varietas Tiron adalah tahan ditanam di musim penghujan. Tujuan dari penelitian ini adalah 1) mengetahui pengaruh empat formula pada pupuk slow release urea terhadap pertumbuhan dan hasil tanaman bawang merah di tanah sawah Purwosari dan 2) mengetahui formula terbaik pada pupuk slow release urea terhadap pertumbuhan dan hasil tanaman bawang merah di tanah sawah Purwosari. Manfaat dari penelitian ini adalah 1) menghasilkan pupuk slow release urea untuk mengoptimalkan penggunaan pupuk $\mathrm{N}$ dalam kegiatan bercocok tanam dan 2) memberikan informasi kepada pembaca bahwa penggunaan pupuk slow release urea dapat menghemat pemupukan oleh petani.

\section{METODE PENELITIAN}

Penelitian dilaksanakan di lahan eks sawah budidaya padi sawah desa Purwosari, Kecamatan Baturraden, Kabupaten Banyumas dan Laboratorium Riset, Universitas Jendral Soedirman pada bulan November 2019 hingga Maret 2020. Bahan yang digunakan dalam penelitian adalah asam humat, montmorilonit dari tanah Vertisol Grobogan, gondorukem, tepung tapioka, pupuk urea, pupuk TSP-46, pupuk KCl, bibit bawang merah varietas Tiron, biomassa Azolla microphylla, air, kitosan, $\mathrm{CH}_{3} \mathrm{COOH}$, campuran selen, $\mathrm{H}_{2} \mathrm{SO}_{4}$ pekat, batu didih, akuades, NaOH, BCG + IMR (Brom Cresol Green + Metil Red), pestisida, dan tanah Inseptisol Purwosari. Alat yang digunakan dalam penelitian ini adalah penggaris, saringan mesh, blender, timbangan elektrik, penggaris, gelas ukur, blender, saringan 70 mesh, cangkul, termohigrometer, mortir, alat tulis, kamera, labu Kjedahl 100 $\mathrm{ml}$, erlenmeyer, soil tester, dan gembor.

Penelitian berupa percobaan lahan non factorial. Rancangan percobaan yang digunakan pada penelitian adalah RAKL (Rancangan Acak Kelompok Lengkap). Rancangan tersebut terdiri atas 5 perlakuan dengan ulangan sebanyak 5 kali sehingga terdapat 25 unit percobaan. Formula pada perlakuan tersebut adalah sebagai berikut:

F0 $=$ N-P-K (Urea, SP-36, dan KCl), F1 $=70 \%$ urea $+6 \%$ kitosan $+24 \%$ asam humat, $\mathrm{F} 2=70 \%$ urea $+10 \%$ Azolla microphylla $+10 \%$ gondorukem $+10 \%$ asam humat, F3 $=60 \%$ urea $+10 \%$ Azolla microphylla $+10 \%$ montmorillonit $+10 \%$ gondorukem $+10 \%$ asam humat, dan F4 $=56 \%$ urea + asam humat $3 \%+$ zeolit $24 \%+$ tepung tapioka $11 \%+$ gondorukem $6 \%$. Variabel yang diamati meliputi pertumbuhan dan komponen hasil tanaman. Variabel pertumbuhan tanaman meliputi tinggi tanaman, jumlah daun, jumlah anakan, bobot tanaman segar, dan bobot tanaman kering. Variabel hasil berupa umbi. Data yang diperoleh dari hasil penelitian dianalisis menggunakan uji F. Uji lanjut DMRT pada taraf kesalahan 5\% dilakukan apabila menunjukkan pengaruh nyata.

\section{HASIL DAN PEMBAHASAN}

Pembahasan dari hasil analisis data adalah sebagai berikut :

\section{Tinggi tanaman}

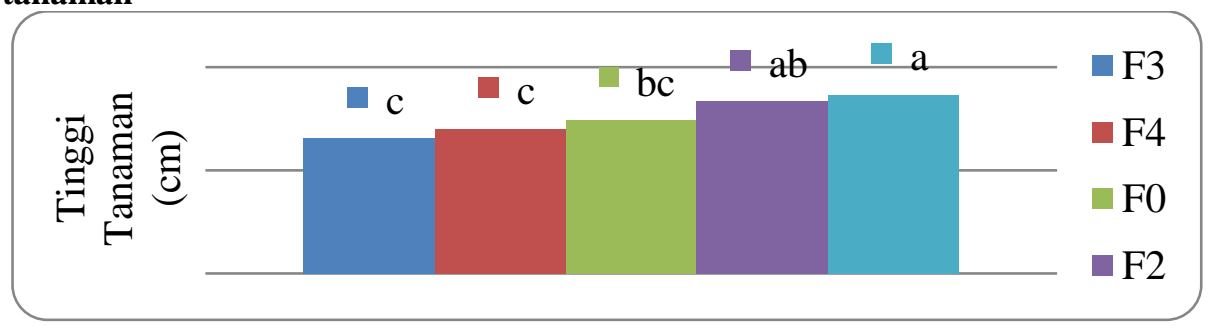

Gambar 1. Histogram Rata-rata Tinggi Tanaman per Rumpun pada Berbagai Formula Pupuk 
Gambar 1 menunjukkan bahwa perlakuan slow release urea F1 menghasilkan tinggi tanaman tertinggi dengan rata-rata $34,72 \mathrm{~cm}$. Hal ini asumsinya asupan unsur hara yang cukup telah tersedia untuk tanaman bawang merah, tetapi belum cukup untuk menggambarkan produksi. Formula F1 terdiri atas urea, kitosan, dan asam humat. Kandungan nitrogen pada F1 sebesar 20,79\%. Dosis yang diberikan untuk memenuhi unsur nitrogen sebesar 2,21 g/tanaman, unsur kalium sebesar 26,6 g/ petak, dan unsur P sebesar 25,5 g/petak.

Pertumbuhan dan pertambahan tinggi tanaman berkaitan erat dengan proses fotosintesis. Hal ini dikarenakan akan menghasilkan fotosintat yang digunakan tanaman untuk proses pertumbuhannya. Hal ini didukung oleh pernyataan Pradnyawan et al. (2005), unsur nitrogen yang diserap tanaman meningkatkan klorofil sehingga hasil fotosintat akan meningkat. Menurut Salisbury \& Ross (1995), fotosintat yang dihasilkan dirombak kembali melalui proses respirasi dan menghasilkan energi. Energi tersebut digunakan oleh sel tanaman untuk melakukan aktivitas berupa pembelahan dan pembesaran sel daun sehingga daun akan tumbuh menjadi lebih panjang dan lebar.

Fase pertumbuhan tanaman memerlukan unsur N, P, dan $\mathrm{K}$ yang cukup terutama dalam pertumbuhan tinggi tanaman. Unsur nitrogen dapat dimanfaatkan tanaman untuk pembentukan klorofil. Fosfor merupakan unsur hara makro yang berperan dalam pembentukan ATP (Adenosin Tri phosphate). Penambahan pupuk KCl berperan dalam pertumbuhan vegetatif tanaman karena memacu kecepatan pertumbuhan tanaman. Hal ini didukung oleh pernyataan Napitupulu \& Winarno (2010), pupuk nitrogen diperlukan tanaman untuk merangsang pertumbuhan tanaman terutama daun. Cahaya yang dapat diterima oleh daun secara merata meningkatkan proses asimilasi yang terjadi sehingga asimilat akan lebih banyak. Asimilat tersebut digunakan sebagai energi pertumbuhan tanaman untuk membentuk organ vegetatif, yaitu daun dan tinggi tanaman. Menurut Gardner et al. (1991) bahwa pertambahan tinggi tanaman terjadi karena pembelahan sel dan peningkatan jumlah sel membutuhkan energi dalam bentuk ATP. Menurut Winarso (2005), fungsi kalium terlibat aktif dalam lebih dari 60 enzim yang mengatur reaksi-reaksi kecepatan pertumbuhan tanaman. Kalium juga berfungsi memperkuat tubuh tanaman dan perkembangan sel tanaman.

\section{Jumlah daun}

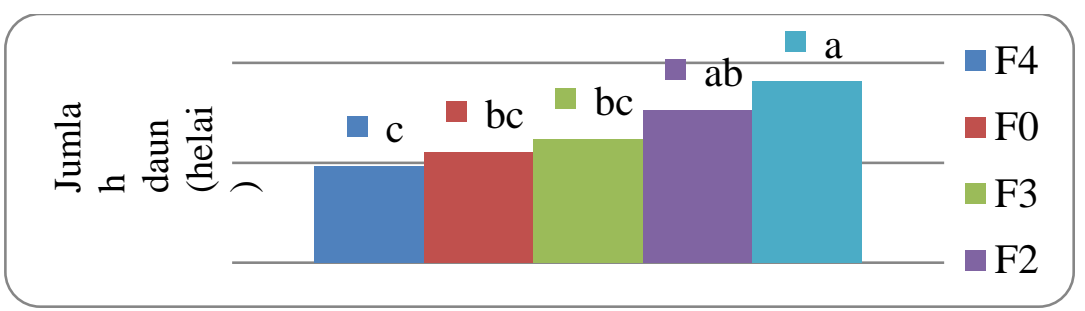

Gambar 2. Histogram Rata-rata Jumlah Daun per Rumpun pada Berbagai Formula Pupuk

Gambar 2 menunjukkan bahwa perlakuan slow release urea F1 menghasilkan jumlah daun tertinggi dengan rata-rata 36,44 helai. Hal ini asumsinya karena penyerapan hara yang lebih optimal terjadi pada tanaman sehingga memiliki daun lebih banyak. Semakin banyak jumlah daun maka memungkinkan telah terjadi penyerapan hara yang lebih optimum.

Formula F1 terdiri atas urea, kitosan, dan asam humat. Kandungan N pada pupuk maka diketahui bahwa kandungan nitrogen pada F1 sebesar 20,79\%. Dosis yang diberikan untuk memenuhi unsur nitrogen sebesar 2,21 g/tanaman, unsur kalium sebesar 26,6 g/ petak, dan unsur P sebesar 25,5 g/petak.

Jumlah daun dipengaruhi oleh unsur hara nitrogen karena merupakan salah satu unsur makro dibutuhkan tanaman sebagai bahan dasar utama membangun protein dan asam nukleat. Hal ini akan menyebabkan tanaman menghasilkan asimilat dalam jumlah cukup. Hal ini didukung oleh pernyataan Wijaya (2008), nitrogen merupakan penyusun dari semua protein dan asam nukleat. Tanaman yang cukup mendapat suplai $\mathrm{N}$ akan membentuk helai daun yang luas dengan kandungan klorofil yang tinggi. Hal ini menyebabkan tanaman dapat menghasilkan asimilat dalam jumlah cukup untuk menopang pertumbuhan vegetatifnya. Jumlah dan luas daun merupakan permukaan yang luas yang memungkinkan penangkapan cahaya dan $\mathrm{CO}_{2}$ yang lebih efektif, sehingga laju fotosintesis meningkat. Hasil fotosintesis ditranslokasikan kedaerah pemanfaatan vegetatif yaitu akar, batang, dan daun yang mempengaruhi pertumbuhan dan perkembangan tanaman. 
3. Jumlah anakan

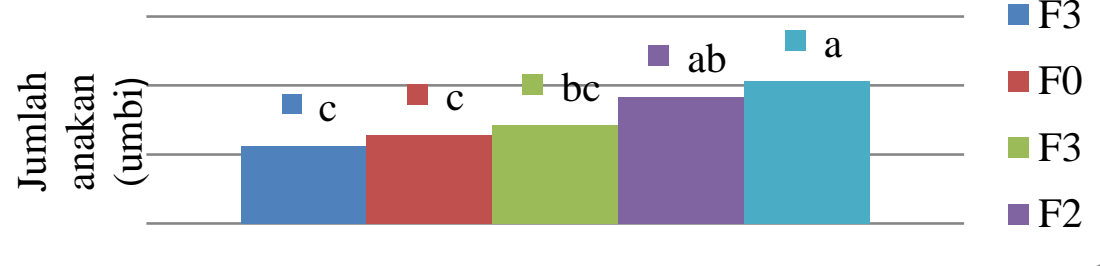

Gambar 3. Histogram Rata-rata Jumlah Anakan per Rumpun pada Berbagai Formula Pupuk

Gambar 3 menunjukkan bahwa perlakuan slow release urea F1 merupakan hasil tertinggi dengan ratarata 4,12 umbi. Hal ini asumsinya karena tersedianya unsur hara $\mathrm{N}$ yang cukup akan memberikan respon positif terhadap jumlah anakan tetapi jumlah anakan yang dihasilkan belum maksimal. Hal ini didukung oleh Supriyatna et al. (2016), proses pembentukan umbi tersebut membutuhkan unsur hara nitrogen yang digunakan untuk pembentukan sel tanaman sehingga pemberian $\mathrm{N}$ yang optimal dapat meningkatkan laju pertumbuhan tanaman. Menurut Wiguna et al. (2013), jumlah anakan yang tinggi dapat menghasilkan jumlah umbi yang tinggi pula. Hal ini disebabkan karena setiap anakan dapat menghasilkan umbi.

Formula F1 terdiri atas urea, kitosan, dan asam humat. Berdasarkan hasil analisis kandungan $\mathrm{N}$ pada pupuk maka diketahui bahwa kandungan nitrogen pada F1 sebesar 20,79\%. Kebutuhan unsur P dipenuhi melalui pemberian SP-36, sedangkan unsur $\mathrm{K}$ melalui pemberian $\mathrm{KCl}$. Dosis yang diberikan untuk memenuhi unsur nitrogen sebesar 2,21 g/tanaman, unsur kalium sebesar 26,6 g/ petak, dan unsur P sebesar 25,5 g/petak.

\section{Bobot tanaman segar}

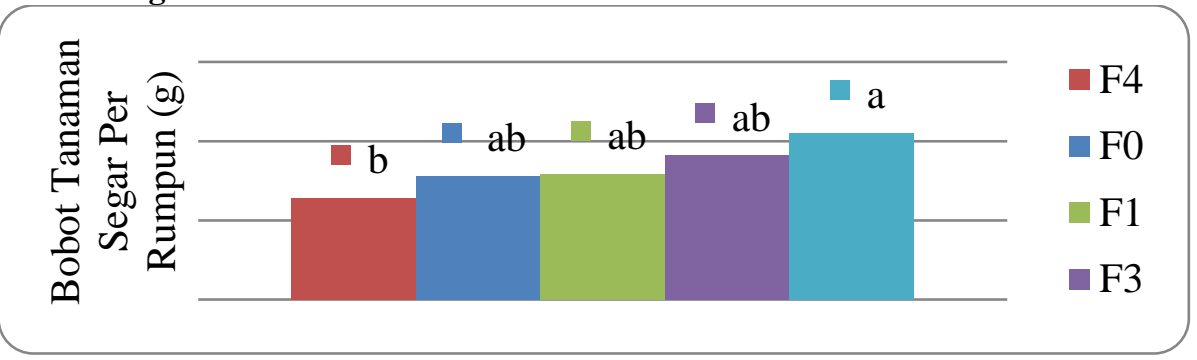

Gambar 4. Histogram Rata-rata Bobot Tanaman Segar per Rumpun pada Berbagai Formula Pupuk

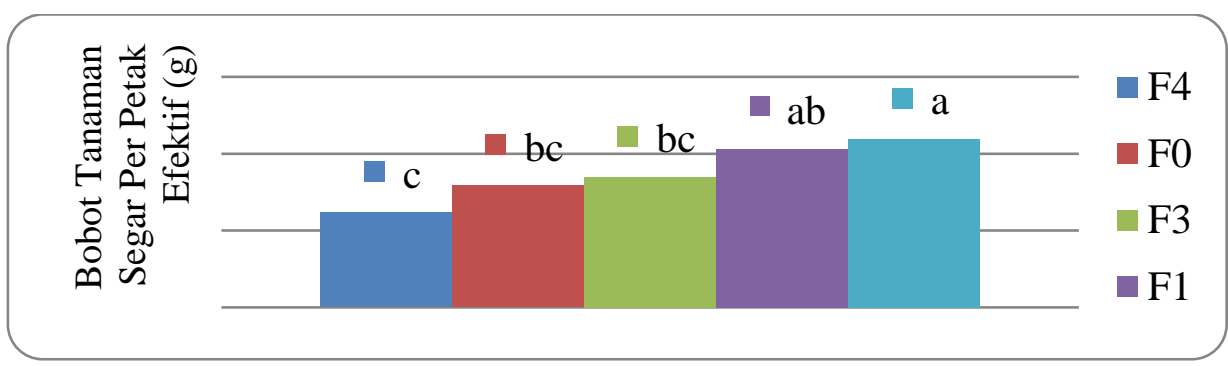

Gambar 5. Histogram Rata-rata Bobot Tanaman Segar per Petak Efektif pada Berbagai Formula Pupuk

Gambar 4 dan 5 menunjukkan bahwa perlakuan slow release urea F2 menghasilkan bobot tanaman segar tertinggi. Hal ini asumsinya karena unsur hara yang diperoleh tanaman akan dimanfaatkan untuk membentuk karbohidrat, protein, dan lemak yang disimpan, sehingga bobot tanaman segar yang dihasilkan akan semakin besar. Formula F2 adalah urea, Azolla microphylla, asam humat, dan gondorukem. Kandungan nitrogen pada F2 sebesar 21,60\%. Dosis yang diberikan untuk memenuhi unsur nitrogen sebesar 2,12 g/tanaman, unsur kalium sebesar 26,6 g/ petak, dan unsur P sebesar 25,5 g/petak.

Nitrogen berperan dalam pembentukan sel tanaman, jaringan, dan organ tanaman. Selain itu, nitrogen memiliki fungsi utama sebagai bahan sintesis klorofil, protein, dan asam amino, asam nukleat, enzim, nukleoprotein, dan alkaloid. Hal ini didukung oleh pernyataan Yahya \& Haryadi (1988), semakin cepat pertumbuhan vegetatif tanaman terutama tinggi tanaman, maka jumlah daun dan perakaran mampu memberikan bobot segar yang lebih besar.

Semakin meningkat tinggi tanaman, maka semakin meningkat pula bobot tanaman segar tersebut. Hal ini didukung oleh pernyataan Menurut Erawan et al. (2013), pemberian pupuk nitrogen yang cukup tinggi ke tanah mampu menyediakan unsur hara dan dapat digunakan untuk pertumbuhan dan perkembangan tanaman bawang

Proceedings homepage: https://conferenceproceedings.ump.ac.id/index.php/pspfs/issue/view/9 
merah lebih cepat dan maksimum. Selain itu, semakin meningkat tinggi tanaman dan luas daun, maka akan semakin meningkat pula bobot tanaman bobot segar konsumsi tanaman tersebut.

\section{Bobot tanaman kering}

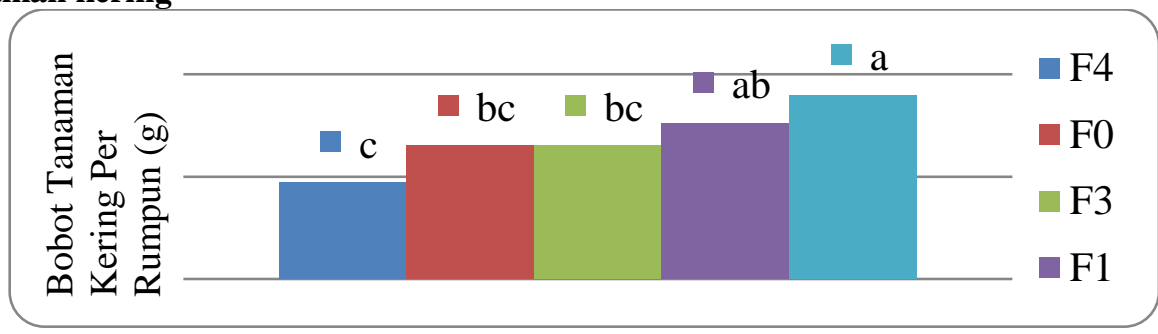

Gambar 6. Histogram Rata-rata Bobot Tanaman Kering per Rumpun pada Berbagai Formula Pupuk

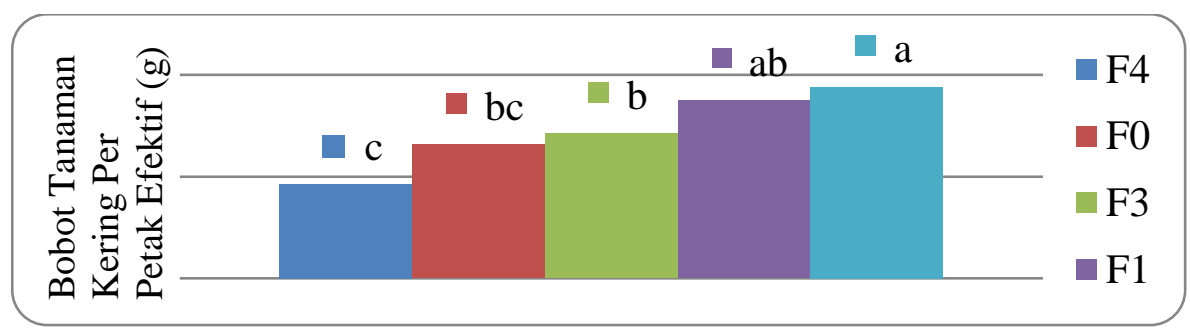

Gambar 7. Histogram Rata-rata Bobot Tanaman Kering per Petak Efektif pada Berbagai Formula Pupuk

Gambar 6 dan 7 menunjukkan bahwa perlakuan slow release urea F2 menghasilkan bobot tanaman kering tertinggi. Hal ini asumsinya karena hara $\mathrm{K}$ yang tersedia bagi tanaman telah optimal sehingga aktivitas fotosintesis meningkat. Unsur $\mathrm{K}$ berperan secara umum untuk pembentukan umbi dan dapat meningkatkan aktivitas fotosintesis dan kandungan klorofil daun sehingga dapat meningkatkan bobot kering tanaman. Anisyah et al. (2014), kandungan $\mathrm{K}$ yang tinggi menyebabkan ion $\mathrm{K}^{+}$yang mengikat air dalam tubuh tanaman akan mempercepat proses fotosintesis. Hasil fotosintesis inilah yang merangsang pembentukan umbi menjadi lebih besar sehingga dapat meningkatkan bobot kering tanaman.

Formula F2 adalah urea, Azolla microphylla, asam humat, dan gondorukem. Kandungan nitrogen pada F2 sebesar 21,60\%. Dosis yang diberikan untuk memenuhi unsur nitrogen sebesar 2,12 g/tanaman, unsur kalium sebesar 26,6 g/ petak, dan unsur P sebesar 25,5 g/petak.

Bobot tanaman kering adalah indikator pertumbuhan tanaman karena merupakan hasil akumulasi asimilat tanaman yang diperoleh dari total pertumbuhan dan perkembangan tanaman selama hidupnya. Hal ini didukung oleh pernyataan Nyakpa et al. (1988) menyatakan bahwa pertumbuhan tanaman dicirikan dengan pertambahan berat tanaman kering, ketersediaan hara yang optimal bagi tanaman akan diikuti peningkatan aktivitas fotosintesis yang menghasilkan asimilat lebih banyak yang akan mendukung berat tanaman kering.

\section{Volume umbi}

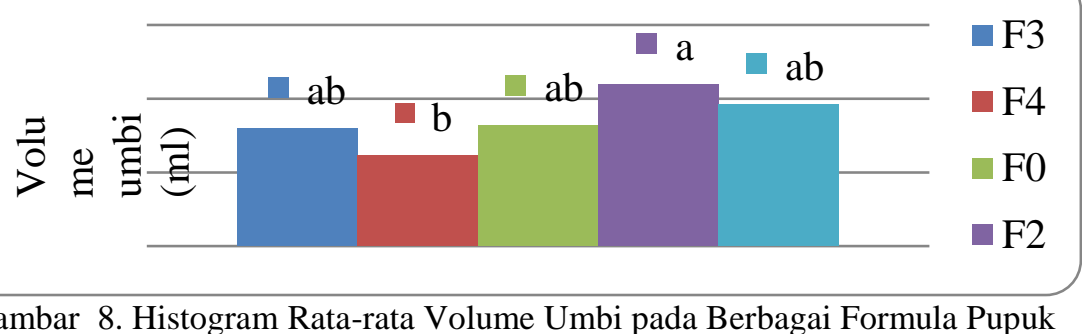

Gambar 8 menunjukkan bahwa perlakuan slow release urea F2 merupakan hasil tertinggi dengan ratarata $10,96 \mathrm{~cm}^{3}$. Hal ini asumsinya karena unsur $\mathrm{N}$ dan $\mathrm{K}$ yang diserap optimal bagi pembentukan umbi. Hal ini didukung oleh pernyataan Wibowo (2004), penambahan unsur hara yang berasal dari pemupukan akan dapat menyediakan unsur hara yang dibutuhkan untuk pertumbuhan umbi bawang merah. Peran unsur $\mathrm{N}$ untuk meningkatkan jumlah daun sehingga meningkatkan laju fotosintesis yang berpengaruh pada karbohidrat yang terbentuk. Fungsi karbohidrat untuk pembentukan umbi dalam fase generatif. Hal ini didukung oleh pernyataan Nur dan Thohari (2005), pemberian nitrogen yang optimal dapat meningkatkan pertumbuhan tanaman, 
meningkatkan sintesa protein, pembentukan klorofil yang menyebabkan warna daun menjadi lebih hijau, dan meningkatkan jumlah daun bawang merah.

Unsur kalium diperlukan tanaman dalam sintesa protein dan karbohidrat serta translokasi karbohidrat yang lebih lancar. Semakin besar bobot umbi maka dapat diasumsikan akan semakin besar volume umbi yang dihasilkan. Hal ini didukung oleh pernyataan Abdulrachman \& Susanti (2004), kalium berperan membantu proses fotosintesis, yaitu pembentukan senyawa organik baru yang diangkut ke organ tempat penimbunan, yaitu umbi. Pengaruh lain dari pemupukan kalium adalah menghasilkan umbi yang berkualitas.

Formula F2 adalah urea, Azolla microphylla, asam humat, dan gondorukem. Kandungan nitrogen pada F2 sebesar 21,60\%. Dosis yang diberikan untuk memenuhi unsur nitrogen sebesar 2,12 g/tanaman, unsur kalium sebesar 26,6 g/ petak, dan unsur P sebesar 25,5 g/petak.

\section{Jumlah umbi}

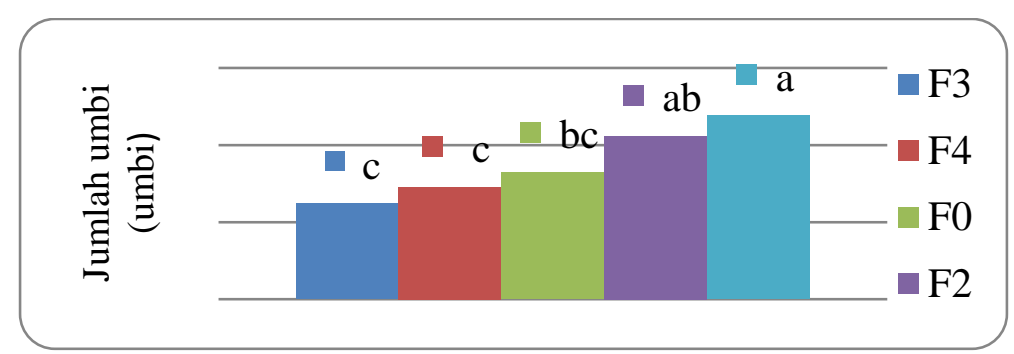

Gambar 9. Histogram Rata-rata Jumlah Umbi per Rumpun pada Berbagai Formula Pupuk

Gambar 9 menunjukkan bahwa perlakuan slow release urea F1 merupakan hasil tertinggi rata-rata 11,92 umbi. Hal ini asumsinya karena tersedianya unsur hara $\mathrm{N}$ dan $\mathrm{K}$ yang cukup akan memberikan respon positif terhadap jumlah umbi. Hal ini didukung oleh pernyataan Ismunadji (2006), pembentukan umbi lebih banyak ditentukan oleh unsur hara makro berupa nitrogen $(\mathrm{N})$ dan potassium $(\mathrm{K})$ dengan dosis yang sesuai. Menurut Pasaribu et al. (2012), kalium berperan sebagai katalis enzimatis pada metabolisme serta pembentukan gula dan pati pada sintesis protein sehingga membantu pembentukan dan pembesaran organ tanaman. Menurut Engelstad (1997), aplikasi N yang optimal dapat meningkatkan pertumbuhan tanaman, jumlah anakan, dan jumlah umbi. Semakin banyak jumlah anakan maka jumlah umbi semakin banyak juga.

Formula F1 terdiri atas urea, kitosan, dan asam humat. Kandungan nitrogen pada F1 sebesar 20,79\%. Dosis yang diberikan untuk memenuhi unsur nitrogen sebesar 2,21 g/tanaman, unsur kalium sebesar 26,6 g/ petak, dan unsur P sebesar 25,5 g/petak.

\section{Bobot umbi kering}

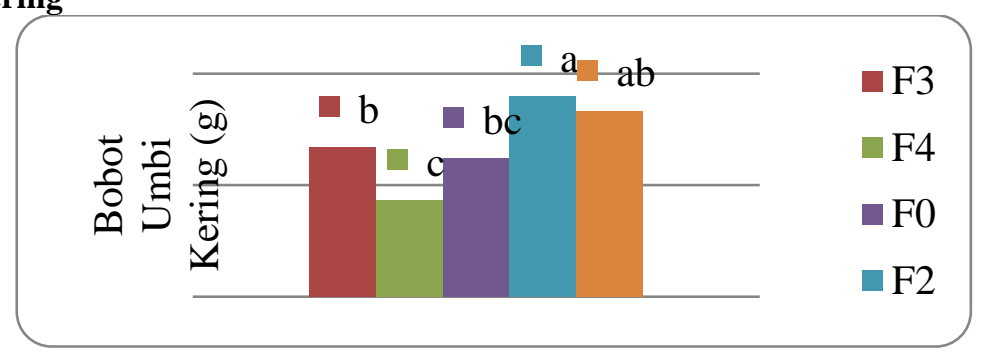

Gambar 10. Histogram Rata-rata Bobot Umbi Kering per Petak Efektif pada Berbagai Formula Pupuk

Gambar 10 menunjukkan bahwa perlakuan slow release urea F2 menghasilkan bobot umbi kering tertinggi dengan rata-rata 35,98 g. Hal ini asumsinya karena unsur $\mathrm{N}$ dan $\mathrm{K}$ yang diserap optimal bagi pembentukan umbi. Hal ini didukung oleh pernyataan Pahlevi et al. (2016), semakin besar penambahan pupuk K yang diberikan maka semakin tinggi pula hasil panen yang dihasilkan. Hasil panen juga dipengaruhi oleh jumlah $\mathrm{N}$ yang diberikan. Hal ini karena apabila tanaman tersebut kekurangan $\mathrm{N}$ yang berakibat rendahnya asimilat yang dihasilkan maka semakin rendah pula jumlah asimilat yang ditranslokasikan ke bagian umbi meskipun penambahan pupuk K yang diberikan tinggi. Menurut Anisyah et al. (2014), kandungan K yang tinggi menyebabkan ion $\mathrm{K}^{+}$yang mengikat air dalam tubuh tanaman akan mempercepat proses fotosintesis. Hasil fotosintesis inilah yang merangsang pembentukan umbi menjadi lebih besar.

Formula F2 adalah urea, Azolla microphylla, asam humat, dan gondorukem. Kandungan nitrogen pada F2 sebesar 21,60\%. Dosis yang diberikan untuk memenuhi unsur nitrogen sebesar 2,12 g/tanaman, unsur kalium sebesar 26,6 g/ petak, dan unsur P sebesar 25,5 g/petak. 


\section{Indeks Panen}

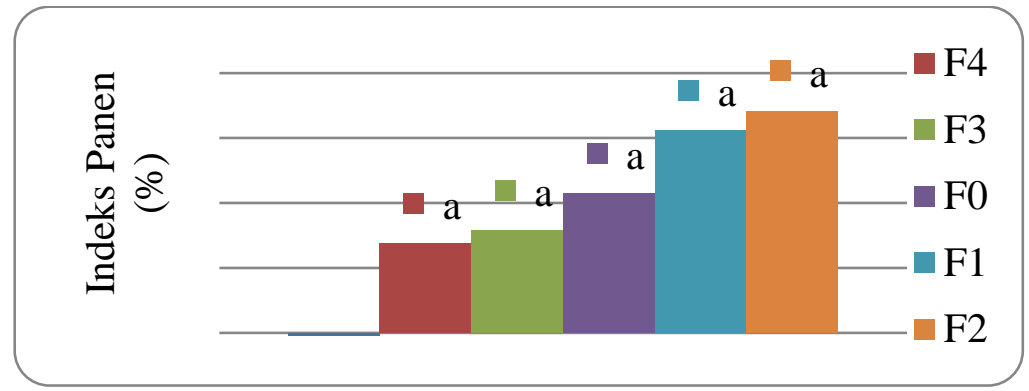

Gambar 11. Histogram Rata-rata Indeks Panen per Petak Efektif pada Berbagai Formula Pupuk

Gambar 11 menunjukkan bahwa perlakuan slow release urea tidak berpengaruh nyata pada variabel indeks panen. Hal ini asumsinya karena ada manfaat coating terhadap urea dengan aneka komposisi bahan. Selain itu, tanaman bawang merah merupakan tanaman sayuran yang dikonsumsi dalam bentuk kering sehingga perhitungan ekonomis lebih ditekankan pada bobot panen kering.

Indeks panen menggambarkan perbandingan antara bobot bahan kering hasil panen biologi dan hasil panen ekonomi serta bergantung pada besarnya translokasi fotosintat. Nilai indeks panen yang diperoleh berkaitan dengan dosis urea yang diberikan. Hal tersebut didukung oleh pernyataan Indradewa (2010), indeks panen merupakan perbandingan antara bagian ekonomi dengan total biomassa. Menurut Prakoso et al. (2018), penambahan pupuk urea pada dosis yang tinggi diduga menurunkan indeks panen karena pendistribusian hasil asimilat sebagian besar diarahkan ke organ vegetatif.

\section{KESIMPULAN}

1. Formula terbaik untuk pertumbuhan dan hasil tanaman adalah F2. Formula F2 terdiri atas $70 \%$ urea $+10 \%$ Azolla microphylla $+10 \%$ gondorukem $+10 \%$ asam humat.

2. Pupuk slow release urea dapat menghemat pemupukan tanaman oleh petani dan mengoptimalkan penyerapan nitrogen oleh tanaman.

\section{DAFTAR PUSTAKA}

Abdulrachman, S. \& Susanti, Z. 2004. Pengaruh pemberian zeolit terhadap peningkatan efisiensi pupuk P dan K pada tanaman padi. Jurnal Zeolit Indonesia, 3(1): 1-12.

Anisyah, F., Sipayung, R., \& Hanum, C. 2014. Pertumbuhan dan produksi bawang merah dengan pemberian berbagai pupuk organik. Jurnal Online Agroteknologi, 2 (2): 482-496.

Engelstad. 1997. Teknologi dan Penggunaan Pupuk. UGM Press, Yogyakarta. 293-322 hal.

Erawan, D., Yani, W.O., \& Bahrun, A. 2013. Pertumbuhan dan hasil tanaman sawi (Brassica juncea L.) pada berbagai dosis pupuk urea. Agroteknos, 3 (1):19-25.

Gardner, F.P., Pearce, R.B., \& Mitchell, R.L. 1991. Physiology of Crop Plant. Universitas Indonesia Press, Jakarta. 423 hal.

Handayani, D.P., Purwito, A., \& Dinarti, D. 2005. Pengaruh jenis sitokinin dan air kelapa terhadap multiplikasi tunas bawang merah (Allium ascalonicum) var. sumenep. Prosiding Seminar Nasional Perhimpunan Hortikultura Indonesia: Menuju Produk Berkualitas, Jakarta.

Indradewa, D. 2010. Fisiologi Tumbuhan. Fakultas Pertanian, UGM, Yogyakarta. 46 hal.

Ismunadji. 2006. Morfologi dan Fisiologi Tanaman. Gramedia, Jakarta. 50 hal.

Jamilah, Erianto, \& Fatimah. 2017. Response of red onion (Allium cepa L.) on time interval and type of liquid organic fertilizer. Jurnal Bibiet, 2(1): 27-36.

Kurniasari, L., Palupi, E.R., Hilman, Y., \& Rosriani, R. 2017. Peningkatan produksi benih botani bawang merah (Allium cepa var. ascalonicum) di dataran rendah subang. J. Hort, 27(2): 201-208.

Nainggolan, G.D., Suwardi., \& Darmawan. 2009. Pola pelepasan nitrogen pupuk tersedia lambat (slow release fertilizers) urea-zeolit-asam humat. Jurnal Zeolit Indonesia, 8(2): 90-96.

Napitupulu, D. \& Winarto, L. 2010. Pengaruh pemberian pupuk N dan K terhadap pertumbuhan dan produksi bawang merah., J-Hort, 20 (1): 72-35. 
Nur, S. \& Thohari. 2005. Tanggap Dosis Nitrogen dan Pemberian Berbagai Macam Bentuk Bolus terhadap Pertumbuhan dan Hasil Tanaman Bawang Merah (Allium ascalonicum L.). Agrijati, 4(1): 30-33.

Nyakpa, M.Y., Lubis, A.M., \& Pulung, M.A. 1988. Kesuburan Tanah. Universitas Lampung, Lampung. 258 hal.

Pahlevi, R.W., Guritno, B., \& Suminarti, N.E. 2016. Pengaruh kombinasi proporsi pemupukan nitrogen dan kalium pada pertumbuhan, hasil, dan kualitas tanaman ubi jalar. Jurnal Produksi Tanaman, 4(1): 16-22.

Pasaribu, M.S., Hasyim, H., \& Winata, H. 2012. Pengaruh penggunaan pupuk anorganik dan organik terhadap pertumbuhan dan produksi bawang merah (Allium ascalonicum L.). Jur. Agrium, 17(2): 108-113.

Pradnyawan,S.W.H., Mudyantini, W., \& Marsusi. 2005. Pertumbuhan, kandungan nitrogen, klorofil, dan karotenoid daun Gynura procumbens (Lour) Merr. pada tingkat naungan berbeda. Jurnal Biofarmasi, 3(1): 7-10.

Prakoso, I. D., Indradewa, D., \& Sulistyaningsih, E. 2018. Pengaruh Dosis Urea terhadap Pertumbuhan dan Hasil Kedelai (Glycine max L. Merr.) Kultivar Anjasmoro. Vegetalika. 7(3): 16-29.

Pratomo, K.R., Suwardi., \& Darmawan. 2009. Pengaruh pupuk slow release urea-zeolit-asam humat (UZA) terhadap produktivitas tanaman padi var. Ciherang. Jurnal Zeolit Indonesia, 8(2): 83-88.

Pusdatin. 2015. Outlook Bawang Merah. Sekertariat Kementerian Pertanian, Jakarta.

Salisbury, F.B. \& Ross, C.W. 1995. Fisiologi Tumbuhan Jilid I. ITB, Bandung. 241 hal.

Sutedjo, M. 2010. Pupuk dan Cara Pemupukan. Rineka Cipta, Jakarta. 175 hal.

Wibowo, S. 2004. Budidaya Bawang, Bawang Merah, Bawang Putih, dan Bawang Bombay. Penebar Swadaya, Jakarta. 54-56 hal.

Wiguna, G., Hidayat, I.M., \& Azmi, C. 2013. Perbaikan teknologi produksi benih bawang merah melalui pengaturan pemupukan, densitas, dan varietas. J Hort, 23(2): 137-142.

Wijaya. 2008. Nutrisi tanaman sebagai penentu kualitas hasil dan resistensi alami tanaman. Agrosains, 9(2): 1215.

Winarso, S. 2005. Kesuburan Tanah: Dasar Kesehatan dan Kualitas Tanah. Gaya Media, Yogyakarta. 350 hal.

Yahya, S. \& Harjadi, S.S. 1988. Fisiologi Stress Lingkungan. Institut Pertanian Bogor, Bogor. 136-176 hal. 